SLOVO, sv. 68 (2018), 199-226, Zagreb 2018.

Viacheslav V. LYTVYNENKO

Protestant Theological Faculty, Charles University

Prague

vyacheslav.lytvynenko@gmail.com
UDK 81 ' $255=14^{\prime} 03=163.1$

27-36Athanasius, sanctus 271.2-722.52Konstantin Preslavski

Izvorni znanstveni članak Primljen: 15. ožujka 2018. Prihvaćen: 11. rujna 2018.

\title{
SELECTIVE TEXTUAL EVIDENCE AS A CASE FOR A SINGLE TRANSLATOR OF ATHANASIUS' ORATIONS AGAINST THE ARIANS INTO OLD SLAVONIC*
}

\begin{abstract}
This study makes a case for a single Slavonic translator of Athanasius' Orations against the Arians and the Epistle to the Bishops of Egypt and Libya (treated as the fourth Oration in the Old Slavonic corpus). For this purpose, it examines eight Greek terms and their Slavonic equivalents that represent the most basic terminology in the vocabulary of the fourth-century trinitarian debates and Athanasius' Orations. The first part of this study provides a terminological table organized around the thematic rubrics, and it is meant to be exhaustive, covering all four writings. The second part provides an analysis of the selected terms based on the data in the terminological table. It explores the patterns of consistency in the way these terms are used throughout the Orations and offers the arguments for why the Slavonic Orations can be perceived as the work of a single translator.
\end{abstract}

Keyw ords: Athanasius of Alexandria, Orations against the Arians, Old Slavonic translation, Constantine of Preslav, Preslav Literary School

\section{INTRODUCTION}

It has been established that among the numerous writings composed by Athanasius of Alexandria (ca. 296/298 - 2 May 373), nine were translated into Old Slavonic, the language also referred to as the Old Church Slavo-

* This study represents research funded by the Czech Science Foundation as the project GAČR 17-07880S »Athanasius of Alexandria, Oratio III contra Arianos: Critical Edition of the Old Slavonic Version«, and by the Charles University Research Centre program No. 204053. 
nic. ${ }^{1}$ Among them, by far the largest and most significant theological work is the Orations against the Arians. In the Slavonic corpus, this work consists of Athanasius' three Orations against the Arians CPG 2093 (ca. 339-345; henceforth CA I, II, III) and his Epistle to the Bishops of Egypt and Libya CPG 2092 (ca. 356, henceforth CA IV). ${ }^{2}$ The Slavonic translation of these four texts was made by Constantine of Preslav in Eastern Bulgaria in 907, and afterwards transmitted under the title of the Orations against the Arians as a single corpus of Athanasian works. Constantine's translation work was done (originally in the Glagolitic script) fewer than 50 years after the invention of the Slavonic alphabet and as such, was very likely to impact many other similar projects. ${ }^{3}$ Today we have 10 Slavonic manuscripts ranging from the $15^{\text {th }}$ to $17^{\text {th }}$ centuries that preserve this work. ${ }^{4}$

While there is a general agreement among scholars that the translation of Athanasius' Orations is the work of Constantine of Preslav, ${ }^{5}$ the fact of

1 LYTVYNENKO; GRITSEVSKAYA 2017. The list of nine Athanasian works translated into Old Slavonic includes the following: three Orations against the Arians (CPG 2093); Epistle to the Bishops of Egypt and Lybia (CPG 2092), known as the Fourth Oration in the Old Slavonic corpus; Life of Antony (CPG 2101); Epistle to Amun (CPG 2106); »Bible canon« from the $39^{\text {th }}$ Festal Epistle (CPG 2102); Epistle to Rufinianus (CPG 2107); and Epistle to Marcellinus on the Interpretation of the Psalms (CPG 2097).

2 As in the case with the Old Slavonic Athanasiana, the Epistle to the Bishops of Egypt and Libya (henceforth as Ep. ad Episc.) sometimes appears with the title of the fourth Oration in several Greek manuscripts. This Oration (=Ep. ad Episc.) should not be confused with the disputed fourth Oration in PG 25.537-539 and in STEGMANN 1917. In some other Greek manuscripts, the disputed fourth Oration is called the fifth Oration. For the most comprehensive analysis of this text, see VINZENT 1996.

3 Most notably, Gregory of Nazianzus (selection of 16 Orations), Basil of Caesarea (Homilies on the Six Days of Creation), Cyril of Jerusalem (Catechetical Lectures, Mystagogic Catechesis), John Chrysostom (numerous Homilies), Cyril of Alexandria (various commentaries), and John of Damascus (Exposition of the Orthodox Faith). On this, see TACHIAOS 2001: $136-139$.

4 On the manuscript tradition and translation of the Orations, see LYTVYNENKO (forthcoming). In addition to the four Orations, the Old Slavonic corpus includes a pseudo-Athanasian text Epistle on the Celebration of Easter, published by PENKOVA 2008. This writing is a translation of the Homily on Easter VII (CPG 4612) attributed to John Chrysostom and edited by FLOËRI; NAUTIN 1957: 111-173.

5 On the person and work of Constantine of Preslav, see e.g. ZYKOV 1978: 34-77. For an updated list of his works with references to the major studies, see TICHOVA 2012: XI, n. 3. The fact that Athanasius' Orations were translated by Constantine is indicated in the Old Bulgarian colophon copied in most of our 10 manuscripts, e.g. in St. Petersburg, RNB, Sobranie

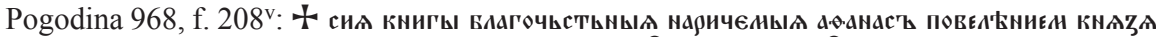

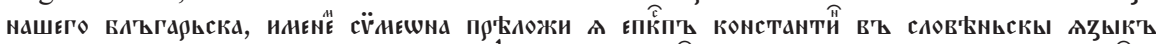

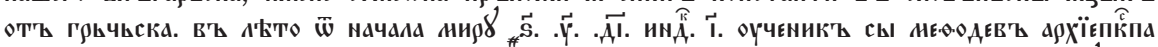

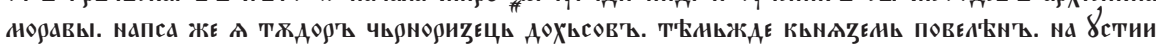


a single translator requires more nuanced evidence after the appearance of P. Penkova's recent publication (PENKOVA 2016.a: 29-37). Based on her analysis of $C A I I$ and $C A I I I$, she suggests that the former underwent a later editorial redaction (in the mid- $10^{\text {th }}$ century) toward a more literal form of the text. More specifically, she contends that while the textual variants in $C A$ $I I$ correspond to the so-called $x$-group of Greek manuscripts, the variants in $C A I I I$ fit a mixed $x$ - and $R S P$ tradition. Penkova also argues that after being subjected to the editorial modification, the Slavonic text of CA II lost some of the most characteristic traits of Constantinian translation - one of them being a free rendering of Greek words instead of following a strict verbatim translation. The question it raises is on what basis can we know that Constantine was the sole translator of all four writings if a significant part of the Slavonic corpus fails to support it?

In this context, I will make a case for a single translator of Athanasius' Orations based on the textual evidence of eight specific terms/word groups. In

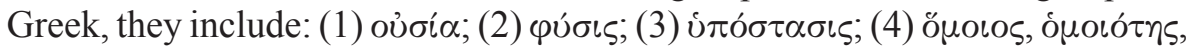

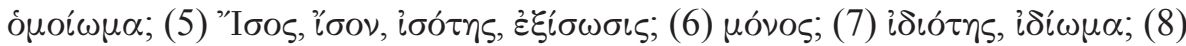
Eiv ${ }^{i} \alpha$. The reason for choosing this terminology is twofold. First, these terms are significant because they form the most basic part of the theological vocabulary in the fourth century debates about God. In his Orations, Athanasius uses them against his Arian opponents to argue that Christ is ontologically equal to God the Father while at the same time being distinct from him as the

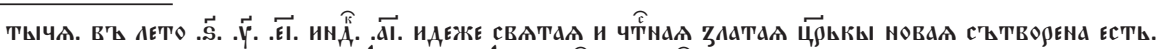

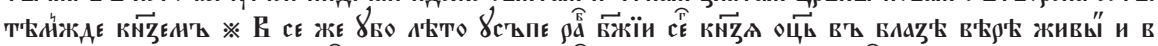

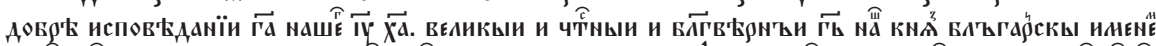

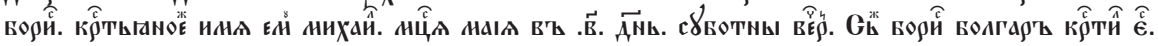

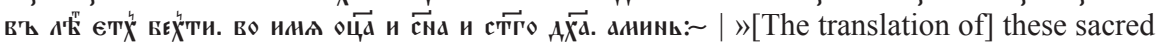
books named after Athanasius of Alexandria was commissioned by our Bulgarian Prince whose name is Symeon, and they were translated by the bishop Constantine (a disciple of Methodius, the Archbishop of Moravia), from Greek into Old Slavonic language in the year $6414 / 10^{\text {th }}$ indict $[=906 \mathrm{sic}$. It was then copied by myself, monk Tudor Duksov (as I was commissioned to do so by the aforementioned Prince) in the holy and sacred »New Golden Church « (whose construction was done by the same Prince) at the Tyča river [= Kamčia river] in the year $6415 / 11^{\text {th }}$ indict [ = $907 \mathrm{sic}$ ]. In that very year, on May 2, Saturday night, there died the father of that Prince, the servant of God, our great and holy and faithful lord, Prince of Bulgaria by the name Boris (who took the name Michael in baptism), after having lived in good faith and in right confession of our Lord Jesus Christ. This very Boris baptized the people of Bulgaria in the name of the Father, Son, and Holy Spirit in the year 6372 [= 864]. Amen « (trans. mine). This colophon was first published by KALAJDOVIČ 1824: 98, and later by GORSKIJ; NOVOSTRUEV 1859: 32-34, n. 111. In 1984 the photocopies of this colophon from different manuscripts were published and discussed by POPKONSTANTINOV; KONSTANTINOVA 1984: 106-118. It has been published numerous other times since then. 
second person of the Trinity who assumed flesh in the incarnation. Second, for all of these terms, Constantine finds two or more Slavonic equivalents, which is (now firmly established) one of the sure signs of the Preslav principles of translation. ${ }^{6}$ Here I suggest that by tracing the consistency with which these specific terms occur throughout the Orations, we can more clearly discern the hand of a single translator.

In light of these considerations, I will divide my study into two parts. The first one will offer a terminological table with the aforementioned eight Greek words and their Slavonic equivalents. This table is meant to be exhaustive and to serve such a function best it covers all four Orations, including the Epistle to the Bishops of Egypt and Libya, which I will call the fourth Oration after its Slavonic title. It will provide the row material which will become the subject of analysis in the second part of this article. Before I introduce that analysis, I would like to spend a few moments explaining which editions I use and how exactly my terminological table is built.

For the Greek terms in the Orations, I will use three editions in the German series of Athanasius Werke (METZLER; SAVVIDIS 1996; METZLER; SAVVIDIS 1998; METZLER; SAVVIDIS 2000). For the Old Slavonic equivalents, I will use a French edition of $C A$ I (VAILLANT 1954), ${ }^{7}$ two recent Bulgarian editions of CA II and CA III (PENKOVA 2015; PENKOVA 2016. a.), ${ }^{8}$ and for the Slavonic text of $C A I V$ (=Ep. ad Episc.), which still remains unedited, I will use the best existing manuscript: St. Petersburg, RNB, Sobranie Pogodina 968, the year 1489 . For every entry in the terminological table, I first give a reference to where it is found in the Greek edition (indicating chapters and lines), and afterwards, in the square brackets, I provide a corresponding place from the Old Slavonic editions (indicating pages/folios and lines). I do the same for $C A I V$ (=Ep. ad Episc.) by numbering the leaves

6 This principle (along with others) was developed in the so-called Preslav Literary School in Eastern Bulgaria and particularly articulated by its leading representative, John the Exarch in the late $9^{\text {th }}-$ early $10^{\text {th }}$ centuries. On this, see POPOVA 2010: 44-47; MILTENOV 2008: 41-49; THOMSON 1991: 35-58; ANGELOV 1987: 22-25; HANSACK 1981: 15-36. According to Černyševa (ČERNYŠEVA 1994: 62-75), the translation principles of the Preslav Literary School were meant to expand the ones employed by Cyril and Methodius. While the former made use of numerous Slavonic equivalents for one single Greek word, the latter employed only one Slavonic equivalent along with the corresponding loanword (e.g. coctab? and ت̈nостась for $i \pi$ ó $\tau \alpha \sigma \iota \varsigma$, where the first is the Slavonic translation, and the second is the loanword adopted from Greek).

7 This edition is based on two manuscripts: St. Petersburg, RNB, Sobranie Pogodina 968, the year 1489; Moscow, GIM, Sinodalnoe sobranie 20, late 1480s - early 1490s.

8 Both editions are based on two manuscripts: St. Petersburg, RNB, Sobranie Pogodina 968, the year 1489; Moscow, GIM, Sinodalnoe sobranie, Usp. VMČ 994, no later than 1552. 
and lines of the manuscript according to the system adopted by Vaillant and Penkova. For practical reasons, I have placed the eight words under the thematic rubrics, and while some of them are quite specific, others are formulated much more generally depending on the particular case in question.

The terminological table will be followed up by the analysis of the Greek terms and their Slavonic equivalents. Wherever appropriate, I will provide a brief note about the theological background and refer the readers to helpful sources for further information. To establish the consistency with which Constantine uses various terms in translating them from Greek, I will make much use of the quantative data from the tables. Wherever there is an issue in the Old Slavonic manuscripts, I will indicate that as well. For every term in my analysis, I will conclude with a summary statement on why I believe the Slavonic Orations to be the work of a single translator.

\section{TERMINOLOGICAL TABLE}

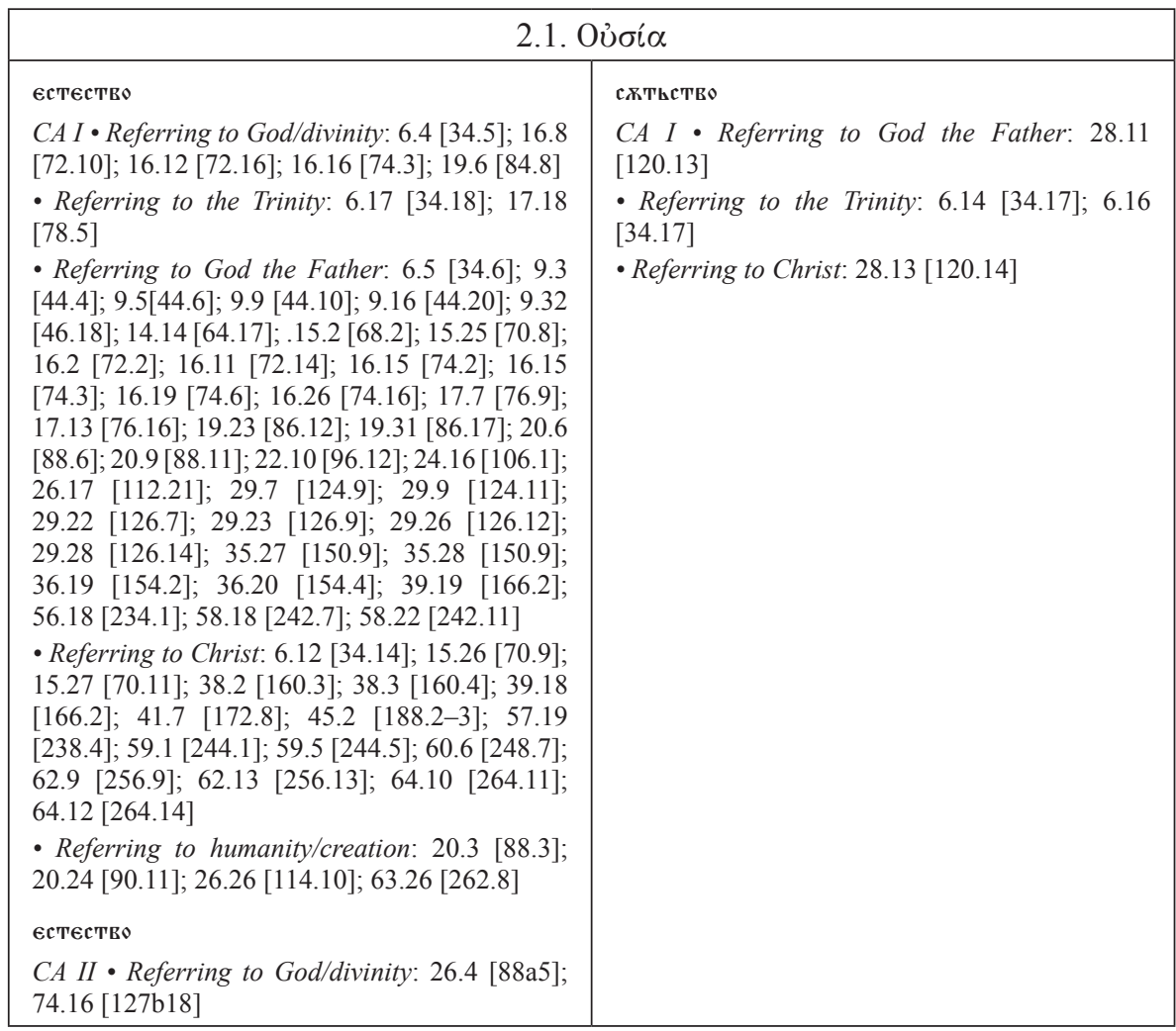


- Referring to God the Father: 2.6 [66a19]; 2.10 [66a27]; 2.15 [66b10]; 2.29 [67a7-8]; 22.12 [84b10]; 31.8 [92a5]; 32.17 [93a19-20]; 32.31 [93b17]; 33.5 [93b26]; 33.21 [94a23-24]; 34.7 [94b14]; 34.14 [94b26]; 38.2 [97b22]; 38.21 [98a26]; 41.3 [100a13]; 42.15 [101b7]; 43.27 [102b16]; 49.21 [107b11]; 56.30 [113b10]; 67.29 [122b6]; 70.16 [124b13-14]

- Referring to Christ: 3.11 [67b5]; 7.14 [71a27]; 9.8 [73a15]; 12.8 [75b23]; 13.11 [76b22-23]; 13.19 [77a12]; 18.1 [80b24]; 22.10 [84b7]; 23.10 [85b5]; 40.9 [99b9]; 40.13 [99b16-17]; 45.1 [103b20-21]; 46.26 [105a19]; 47.25 [106a10]; 49.13 [107a25-26]; 49.15 [107b1-2]; 51.11 [108b25]; 51.13 [108b27]; 56.25 [113b4]; 60.4 [116a26]; 64.10 [119b9]; 64.13 [119b13]; 64.14 [119b16]; 66.4 [120b25]; 67.10 [122b27]; 71.4 [125a2]; 78.24 [131a16]; 79.11 [131b7]; 80.8 [132a22]; 80.24 [132b19, 22]; 82.22 [134a24]

- Referring to humanity/creation: 3.9 [67b1]; 11.12 [75a10]; 17.13 [80b3-4]; 17.16 [80b1011]; $17.21 \quad[80 \mathrm{~b} 20] ; 19.30 \quad$ [82b22]; 27.26 [89a20]; 28.2 [89b7]; 33.7 [94a2]; 33.9 [94a4]; 33.18 [94a20]; 34.2 [94b5]; 34.3 [94b7]; 45.5 [103b27]; 46.1 [104b5]; 46.9 [104b18]; 46.11 [104b21]; 46.16 [105a2]; 46.25 [105a18]; 53.2 [110b1]; 56.1 [112b18-19]; 64.2 [119a23]; 79.25 [132a2]; 81.5 [133a7]

- Referring to the primacy of substance over words: 3.8-9 [67a26]

- Referring to the semantic aspect of nature: 45.6 [104a3]; 46.3 [104b9]

- Referring to nature in the sense of general category: 79.25 [132b24-25]

\section{єстество}

CA III - Referring to God the Father: 3.11 [135b26]; 3.7 [136b11]; 3.12 [136b20]; 3.17 [136b26-27]; 5.4 [137b16]; 5.5 [137b16]; 6.6 [138b2]; 6.14 [138b16]; 6.21 [138b27]; 8.28 [140b25]; 12.1 [143b13]; 14.25 [146a6]; 15.12 [146b6]; 17.15-16 [148b4-5]; 27.14 [156b27]; 56.2 [178a14]; 62.12 [183b20]; 63.17 [184b17]; 63.20 [184b22]; 65.24 [186b7]; 65.26 [186b11]; 66.8 [187a5]; 66.20 [187a26]

- Referring to Christ: 6.13 [138b15]; 11.2 [142b26]; 16.40 [148a6]; 19.22 [150a27]; 26.5 [155a26]

- Referring to the identical nature between the Father and Son: 66.25 [187b6-7]

- Referring to humanity/creation: 11.10 [143a11]; 67.14 [188a11]

\section{сXTLCTBO}

CA III • Referring to Christ: 35.20 [163b12-13]; 36.11 [164a9] 
єстєство

CA IV • Referring to God the Father: 12.15

[198a24]; 12.20-21 [198b6-7]; 13.24 [199b14];

17.13 [202b25]

- Referring to Christ: 12.38 [199a7]

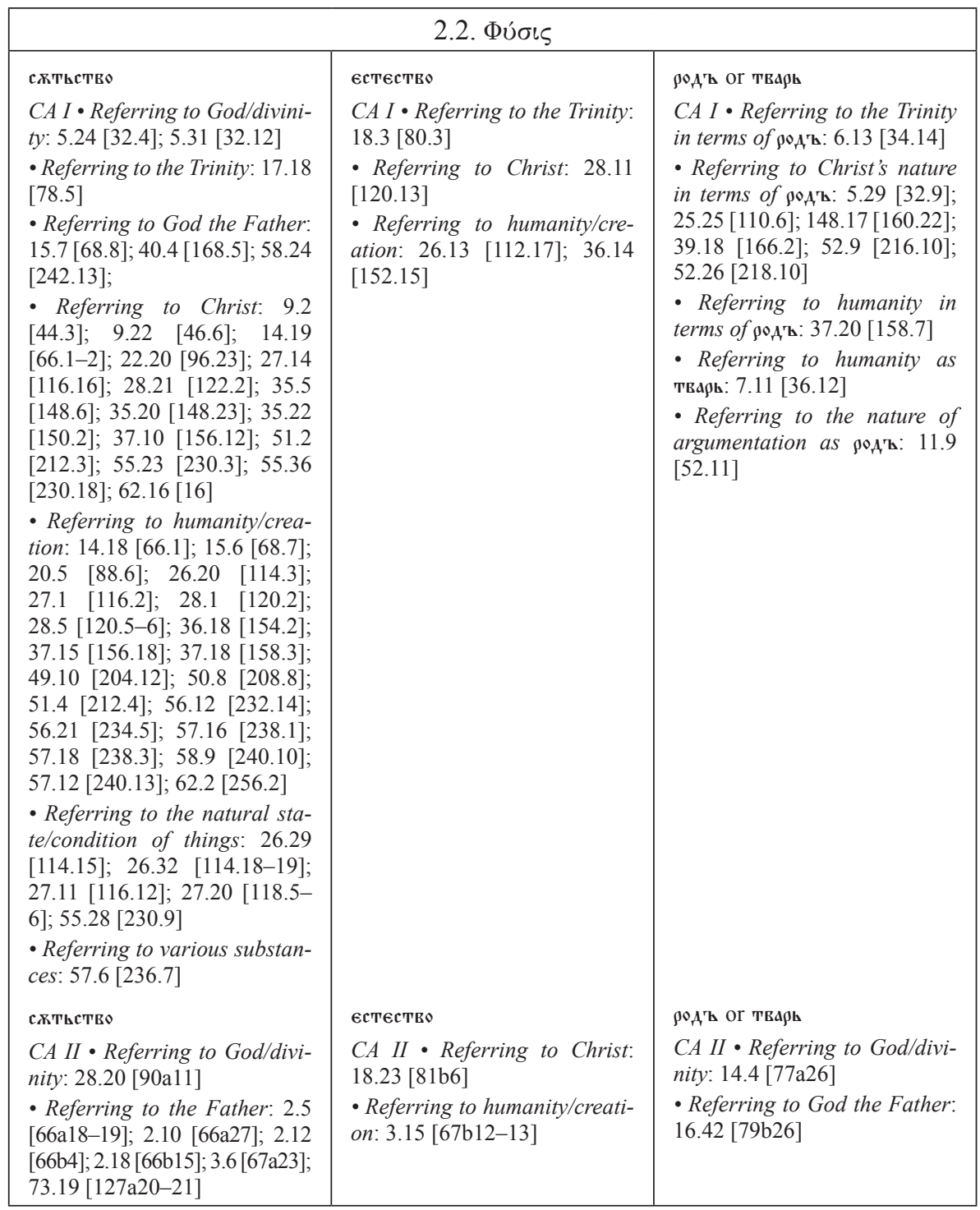




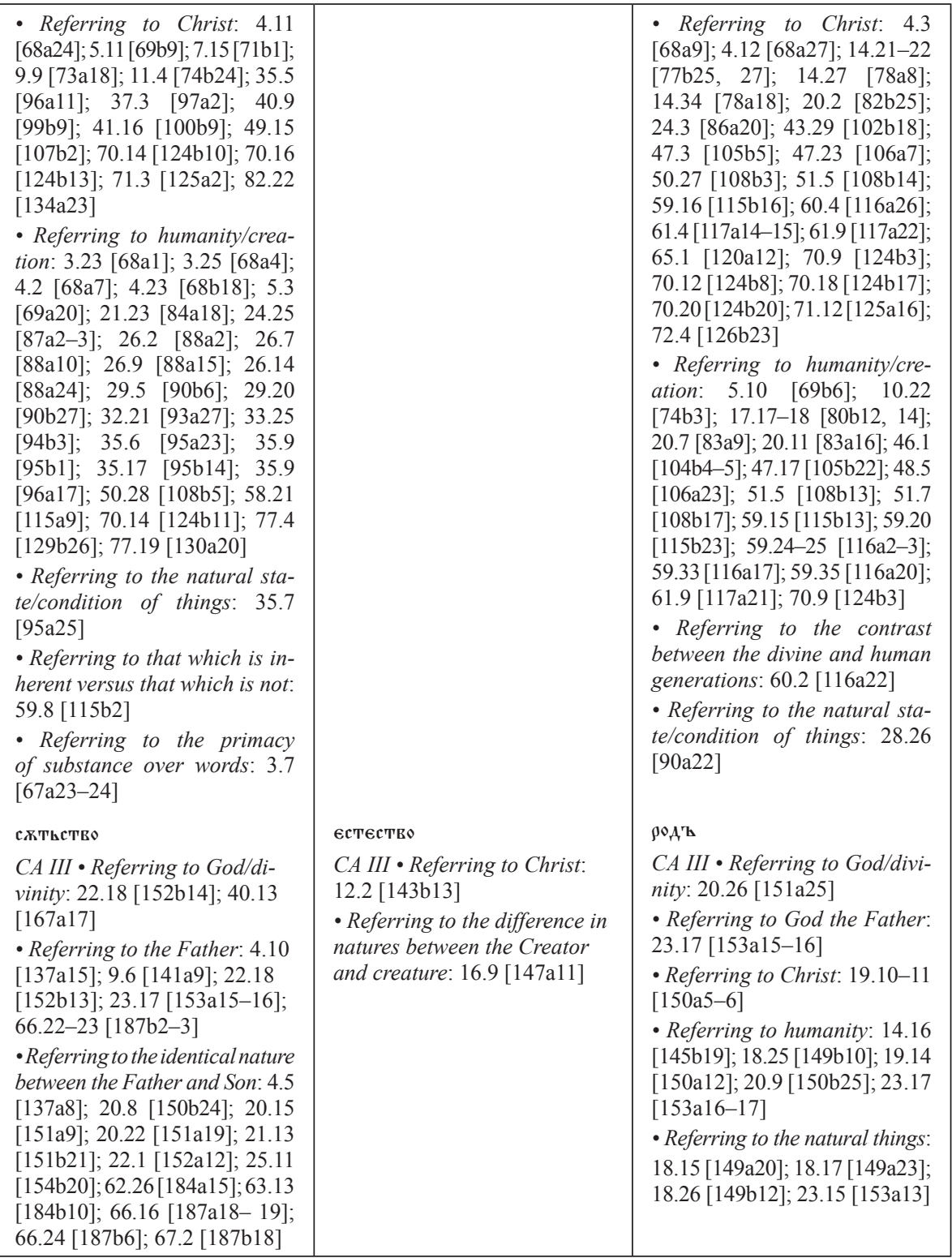


- Referring to Christ: 9.18 [141b1-2]; 10.29 [142b18]; 17.23 [148b16]; 19.22 [150a26 $-27] ; 20.12 \quad[151 \mathrm{a} 5] ; 24.5$ [153b17]; $26.5 \quad[155 \mathrm{a} 25]$; 26.11-12 [155b10-12]; 26.19 [155b25]; 27.18 [157a6]; 28.18 [157b24]; $32.23 \quad[161 \mathrm{a} 7-8]$; 34.1 [162a5]; 34.14 [162a2526]; $34.14 \quad[162 \mathrm{a} 25] ; 34.15$ [162b1]; 34.18 [162b5]; 55.1 [177b1]; 61.10 [182b22-23]; 63.20 [184b21]; 65.31 [186b1819]; 66.1 [186b21]

- Referring to humanity/creation: 14.4 [145b1-2]; 18.7 [149a7]; 20.14 [151a7]; 33.11 [161b1]; 34.23 [162b15]; 34.25 [162b18-19]; 34.27 [162b22]; 34.30 [162b27]; 43.6 [168b25]; 53.17 [176b7]; 53.20 [176b1112]; 57.32 [180a7]; 58.3 [180a15-16]; 60.10 [182a8]; 62.11 [183b18]; 62.22 [184a910]; 67.13-14 [188a10]; 67.17 [188a17]; 67.20 [188a22]

- Referring to the common nature and names: 18.5 [149a3]

- Referring to the nature(s) of pagan gods: 16.18 [147a25]; 16.21 [147b4]

- Referring to the angels: 12.12 [144a3]

- Referring to natural things or conditions: 18.17 [149a23]; 20.23 [151a21]; 23.15 [153a13]; 57.28 [179b26]; 62.10 [183b16]; 62.15-16 [183b24, 26]; 66.27 [187b10]; 66.28 [187b11-12]

- Referring to the nature of what is being said: 41.8 [167b17]

\section{сжтиство}

CA IV - Referring to God the Father: 12.15 [198a23]; 16.19 [201b27]

- Referring to the identical nature between the Father and Son: 12.28 [198b18]

- Referring to natural things and conditions: 13.27 [199b20]

$\rho \circ A^{\prime} \mathbf{k}$

CA IV $\bullet$ Referring to Christ in terms of $\rho \circ \mathrm{A} \mathbf{\mathrm { k }}$ : 12.8 [198a12] 


\begin{tabular}{|c|c|}
\hline \multicolumn{2}{|c|}{ 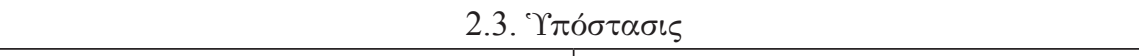 } \\
\hline 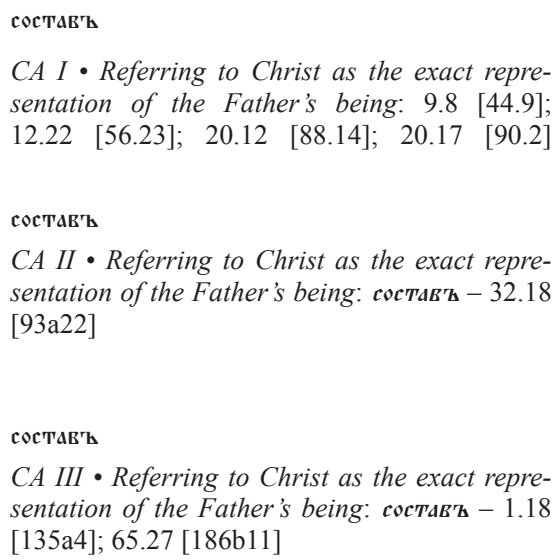 & 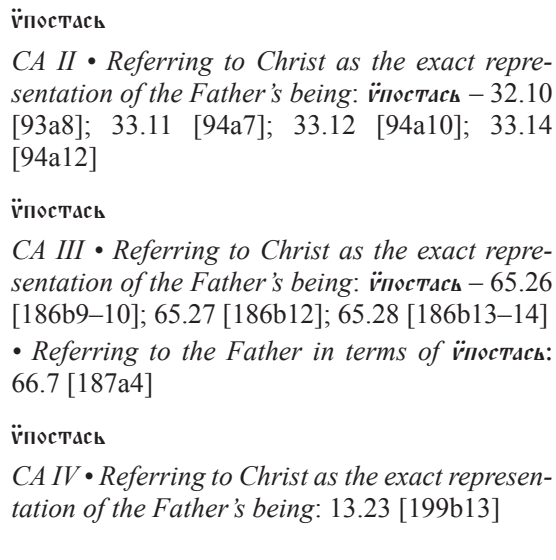 \\
\hline
\end{tabular}

\begin{tabular}{|c|c|}
\hline \multicolumn{2}{|c|}{ 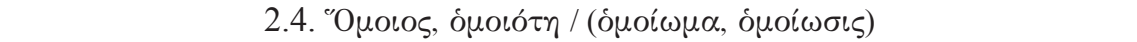 } \\
\hline 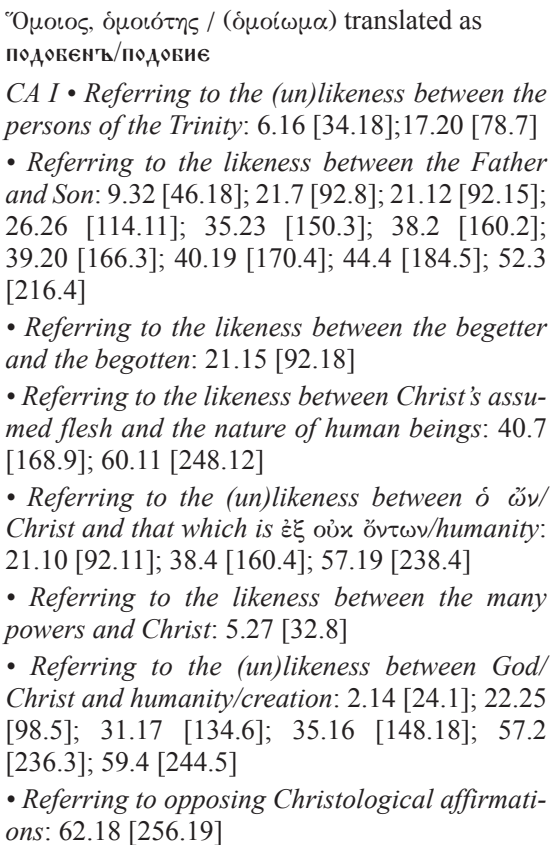 & 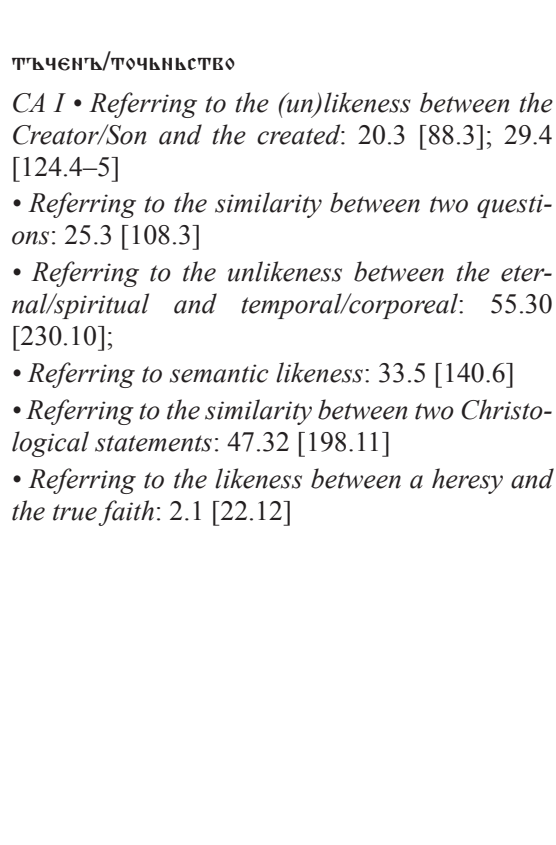 \\
\hline
\end{tabular}




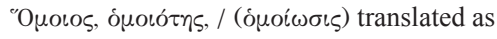
ПОАОБЕн'ъ/ПОАОБИє

$\mathrm{CA} I \mathrm{I} \cdot$ Referring to the likeness between the Father and Son: 17.7 [80a21]; 18.12 [81a13]; 22.10 [84b7]; 42.15 [101b7]; 49.16 [107b3-4]; 82.7 [133b27-134a1]

- Referring to the likeness between Christ's assumed flesh and the nature of human beings: 9.9 [73a19]; 10.30 [74b16]; 52.11 [109b24]; 55.11 [112a8]; 61.12 [117a27]; 61.14 [117b2]; 63.13 [118b22]; 70.7 [124.27]; 74.18 [127b21]; 75.32 [128a17]
\end{abstract}

- Referring to the (un)likeness between God/ Christ and humanity/creation: 6.26 [70b25]; 49.19 [107b7]; 64.4 [119a26]; 64.6 [119b2]

- Referring to the similarity between several Christological affirmations: 11.27 [75b10]; 13.21 [77a14]; 17.3 [80a15-16]; 17.18 [80b15-16]

- Referring to analogy: 79.26 [132a4]

- Referring to the likeness between several actions: 27.3 [88b9]

- Referring to similarities between the Old Testament prophecy and their fulfillment in Christ: 51.28 [109b1-2]

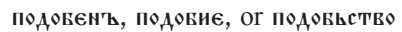

CA III $\bullet$ Referring to the (un)likeness between the Father and Son: 10.2 [141b27]; 10.11 [142a9]; 11.4 [143a2]; 11.8 [143a8]; 11.12 [143a14]; 17.15 [148b3]; 20.12 [151a4]; 26.5 [155a26]; 36.2 [163b22]; 36.5 [164a1]; 36.18 [164a22]; 44.20 [169b26]; 66.25 [187b7]

- Referring to the way the Son's likeness with the Father ought to be related to his essence: 11.2 [142b25-26]

- Referring to the Son's likeness with the Father in respect to the doctrines and the teaching (and therefore only by name rather than nature): 11.6 [143a5]

- Referring to the similarity between the Arian and pagan thinking about God: 16.15 [147a19]

- Referring to one becoming like God: 17.20 [148b11]

- Referring to the similarity between Adam's action and other people's deeds: 33.10 [161a25]

- Referring to the (un)likeness between Christ and humanity: 17.2 [148b25]; 17.4 [149a2]; 24.23 [154a18]; 36.18 [164a22]; 45.12 [170b4]; 53.3 [176a11]

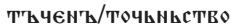

CA II - Referring to the unlikeness between the Father and Son: 34.9 [94b25]

- Referring to the likeness between several beings: 27.3 [88b9]; 67.22 [122a20]

- Referring to the likeness between Christ's assumed flesh and the nature of human beings: 74.1 [127b11]

- Referring to the likeness between the vine and its branches: 74.17 [127b17]

- Referring to the likeness between several people: 27.5 [88b14]

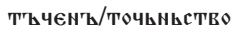

CA III - Referring to the similarity between several Christological statements: 31.13 [160a]; 66.21 [187b1] 
- Referring to the similarity between several Christological affirmations: 26.15 [155b17-18]; 31.13 [160a]; 36.7 [164a3]; 36.15 [164a16]; 56.2 [178a15]; 65.21 [186b2]

- Referring to the (un)likeness between God the Father and human beings: 10.19-20 [142b1, 3]; 10.28 [142b16]

- Referring to the natural relatedness of things that are alike: 20.10 [151a1-2]

- Referring to the way the king's image resembles his actual appearance: 5.16 [138a7]; 5.18 [138a11]

- Referring to the way Paul's teaching is like that of the Savior, while his essence is not: 11.10 [143a11]; 11.10 [143a11-12]

- Referring to the way $x \alpha \theta \omega \dot{\varsigma}$ can be interpreted as similar: 23.7 [152b27]

- Referring to the likeness between parents and their children: 67.14 [188a11]; 67.17 [188a15-16]

ПОдОБен7//ПОдОБие

CA IV $\bullet$ Referring to one becoming like God: 2.15 [190a17]

- Referring to the way Arians have similar beliefs about Christ as demons: 14.7 [200a14]

- Referring to the likeness between the Father and Son: 17.11 [202b21]; 17.13 [202b24]

\begin{tabular}{|c|c|}
\hline \multicolumn{2}{|c|}{ 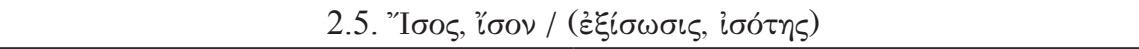 } \\
\hline $\begin{array}{l}\text { T"вчєн' } \\
\text { CA I - Referring to the Son's equality with the } \\
\text { Father: } 40.6[168.8] ; 16.3 \text { [72.4] } \\
\text { - Referring to the Son's equality with the Holy } \\
\text { Spirit: } 50.16 \text { [208.18] } \\
\text { - Referring to the equality between two Chri- } \\
\text { stological statements: } 17.5 \text { [76.6]; } 19.9 \text { [84.11]; } \\
44.21 \text { [186.1] }\end{array}$ & 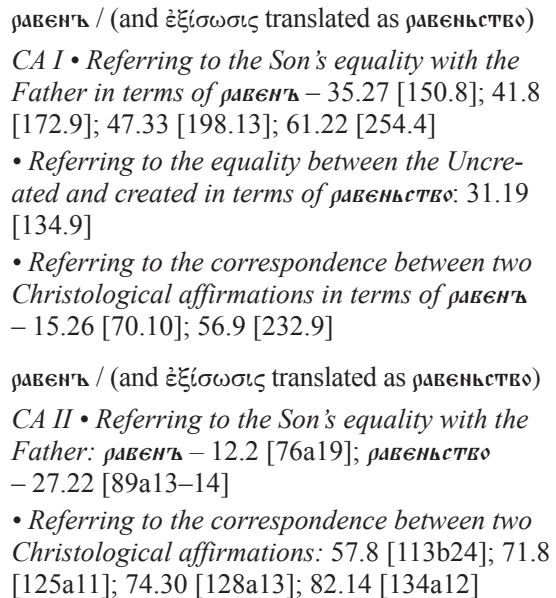 \\
\hline
\end{tabular}




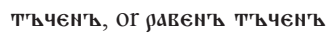

CA III $\bullet$ Referring to the equality between humans

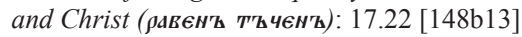

- Referring to the equality between two Christological statements (тъченъ): 31.11 [159b22]

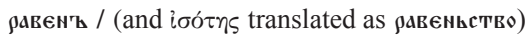

CA III - Referring to the Son's equality with the Father: 6.2-3 [138a24-25]; 27.16-17 [157a3, 5]; 29.12 [158b16]; 51.10 [174b11]

- Referring to the equality between the gift and the Giver: 17.21 [148b13]

- Referring to the equality between two Christological affirmations: 21.15 [151b25]; 27.22 [157a12]

- Referring to $\varkappa \alpha \theta \omega$ s as not implying equality: 22.19 [152b16]; 23.6 [152b26]

- Referring to the inequality between Christ/God and people: 24.23 [154a18]; 25.24 [155a15]

- Referring to one becoming like angels: 51.17 [174b24]

\subsection{Móvos}

\section{ЄAнN'}

CA I - Referring to the Father/divinity: 5.11 [30.10]; 5.15 [30.15]; 23.17 [102.5]; 26.6 [112.7]; 31.11 [132.12]; 43.5 [180.5]

- Referring to Christ: 9.4 [44.5]; 9.20 [46.3]; 10.28 [50.15]; 31.20 [134.10]; 35.10 [148.12]; 39.17 [164.19]; 44.12 [184.14]; 46.11 [192.14]; 56.18 [234.1]; 59.22 [244.24]

- Referring to Israel: 43.3 [180.3]

- Referring to the idea of exclusiveness or limitation: 20.8 [88.10]

\section{$\epsilon_{\text {дин'ъ }}$}

CA II - Referring to the Father or God/divinity: 10.5 [74a2]; 23.17 [85b17]; 24.17 [86b16]; 24.18 [86b19]; 24.21 [86b25]; 24.26 [87a5-6]; 26.15 [88a25-26]; 27.8 [88b19]; 29.4 [90b4]; 29.6 [90b7]; 29.7 [90b8]; 30.17 [91b2]; 31.4 [91b27]; 35.5 [96a11]; 39.24 [99a17]

- Referring to Christ: 20.17 [83a27]; 22.14-15 [84b14-15]; 22.21 [84b24-25]; 22.23 [85a2]; 23.6 [85a26]; 23.10 [85b5]; 24.11 [86b6]; 24.18 [86b19]; 25.4 [87a15]; 25.8 [87a21]; 26.3 [88a3]; 30.17 [91b2]; 39.5 [98b10]; 39.11 [98b20]; 39.13 [98b24]; 41.3 [100a13]; 48.17 [106b15]; 49.17 [107b4]; 64.21 [120a1]; 81.27 [133b16]

- Referring to individual people or created realities: 27.15 [89a3]; 27.27 [89a22]; 28.1 [89b6]; 99.20 [99a9]; 48.4 [106a20]; 48.25 [107a2]

- Referring to the idea of exclusiveness or limitation: 21.22 [84a18]; 17.8 [80a24]; 38.1 [97b18]; $64.5[119 \mathrm{~b} 1]$ сц'宀гл'

CA II - Referring to Christ: 24.26 [87a6]; 27.23 [89a15]; 49.13 [107a24]

- Referring to individual people or created realities: 27.24 [89a17]; 28.10 [21] 
EAнн'

CA III - Referring to the Father or God/divinity: 6.25 [139a8]; 6.27 [139a12]; 8.3 [140a11]; 8.11 [140a22]; 9.1 [140b27]; 9.10-11 [141a16]; 9.13 [141a20]; 14.4[145b1]; $15.9 \quad[146 \mathrm{a} 27] ; 21.4 \quad[151 \mathrm{~b} 5] ; 38.9 \quad[165 \mathrm{~b} 15] ; 52.6$ [175a25]; 66.14 [187a14]

- Referring to Christ: 2.20 [135b24]; 10.18 [142a26]; 10.19 [142b1]; 10.29 [142b18]; 13.15 [145a7]; 16.26 [147b10]; 18.10 [149a12]; 21.3-4 [151b5-6]; 35.20 [163b12]; 36.13 [164a13]; 37.22 [165a26]; 52.5 [175a2223]; 52.6 [175a24]; 66.14 [187a14]

- Referring to humanity/created realities: 8.7 [140a18]; 23.5 [152b24]; 33.18 [161b13]; 38.16 [166a1]

- Referring to the idea of exclusiveness or limitation: 9.23 [141b10]; 17.2 [148b25]; 22.18 [152b14]; 36.4 [163b26]

EAнH'

CA IV • Referring to God the Father: 12.23 [198b11]

- Referring to Christ: 14.8 [200a15-16]; 14.11

[200a20]; 16.6 [201b5]

- Referring to the idea of exclusiveness or limitation: 17.26 [203a19]

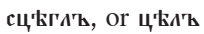

CA III - Referring to the Father or God/ divinity as cцtriz - 6.28-29 [139a1415]; 6.30 [139a17]; 7.3 [139a26]; 8.28 [140b26]; 9.11 [141a17]; 9.13 [141a21];

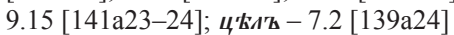

- Referring to Christ: cцtгат - 6.29 [139a15]; 9.12 [141a17]; 9.17 [141a26]; 17.3 [148b27]

\begin{tabular}{|c|c|c|}
\hline \multicolumn{3}{|c|}{ 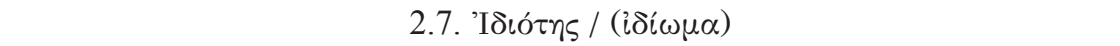 } \\
\hline свонство & ПЛИсносХШТАСТЕО & \\
\hline $\begin{array}{l}C A I \cdot \text { Referring to the Son's } \\
\text { relation to the Father: } 29.9 \\
{[124.11] ; 42.3[176.4] ; 58.26} \\
{[242.15]}\end{array}$ & $\begin{array}{l}C A I \cdot \text { Referring to the Son's re- } \\
\text { lation to the Father: } 6.5 \text { [34.6] }\end{array}$ & \\
\hline своиство / (своиство) & Присносжштьстьво & (ОББІЧАи) \\
\hline 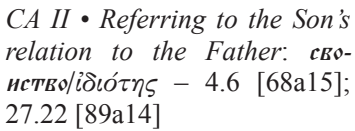 & $\begin{array}{l}C A I I \cdot \text { Referring to the Son's } \\
\text { relation to the Father: } 62.8 \\
{[118 \mathrm{a} 2]}\end{array}$ & 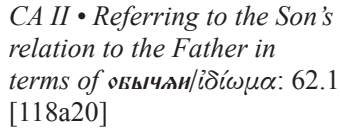 \\
\hline 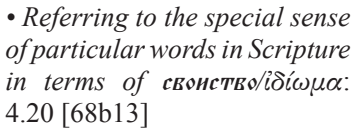 & & \\
\hline своиство & & \\
\hline CA III $\bullet$ Referring to the Son's & & \\
\hline relation to the Father: 4.9 & & \\
\hline $\begin{array}{l}{[137 \mathrm{a} 14] ; 5.23 \text { [138a9]; } 6.10} \\
{[138 \mathrm{~b} 10] ; 11.8-9 \quad[143 \mathrm{a} 8-9] ;}\end{array}$ & & \\
\hline 16.39 [148a5]; 36.18 [164a22]; & & \\
\hline 66.25 [187b7] & & \\
\hline - Referring to the Son's relati- & & \\
\hline $\begin{array}{l}\text { on to his assumed body: } 54.2 \\
\text { [176b14] }\end{array}$ & & \\
\hline
\end{tabular}




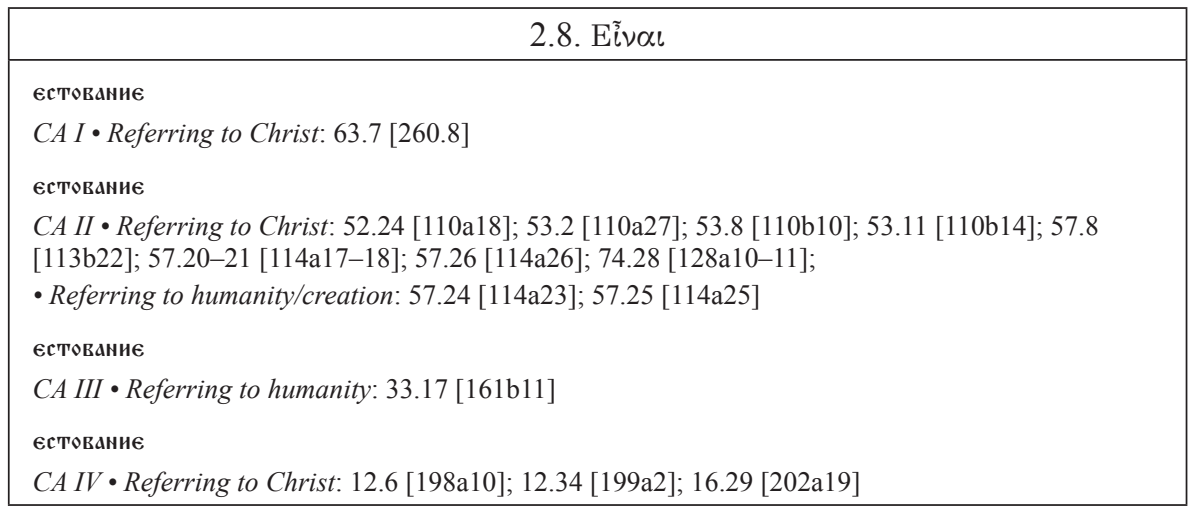

\section{ANALYSIS}

\subsection{Oủoí $\alpha$}

The word oủ ${ }^{\prime} \alpha$ (trans. as 'being', 'substance') has a long history before it was appropriated by Athanasius for the description of God in the trinitarian debates. ${ }^{9}$ At the time he was composing his first three Orations in 339-345,

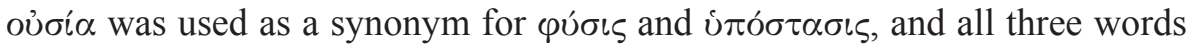
could refer either to a single person of the Trinity, or to the common nature of the Godhead. ${ }^{10}$ This is exactly the kind of ambiguity we find in the Orations, and it is not until after 362 that a deliberate distinction began to be made be-

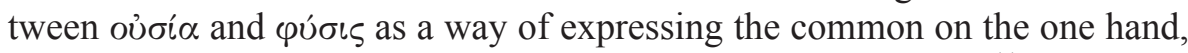
and $\dot{\delta} \pi \delta \sigma \tau \alpha \sigma \iota \varsigma$ as a way of depicting the individual on the other. ${ }^{11}$

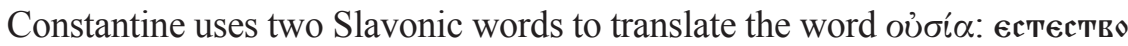
and сктиство. Of these two, he clearly prefers єстество over сктьство in CA I and $C A I I I$ (65 over 4 in $C A I ; 31$ over 2 in $C A I I I)$, and he never uses скттствь

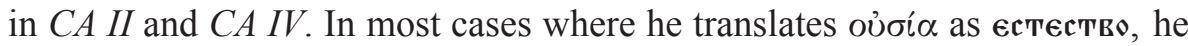
does so to describe God rather than humanity (61 over 4 in $C A I ; 29$ over 2 in

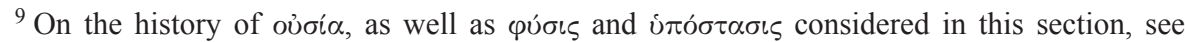
STEAD 1977 and ZIZIOULAS 1997: 27-67. For a more specific discussion that concerns Athanasius, see ZIZIOULAS 1997: 83-89. For a discussion of ontological language in Athanasius' Orations, see LYTVYNENKO 2014: 204-233. For a discussion of the Slavonic rendering of oủoi $\alpha$ in various texts, including those of the Preslav School, see HRISTOVASHOMOVA 2016: 93-107.

${ }^{10}$ BEHR 2004: 158.

11 GITTON 2006: 375-405.
} 


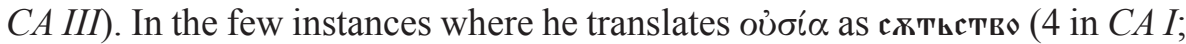
2 in $C A I I I)$, this term is used to depict God and is never applied to humanity.

Thus, we have a clear pattern of consistency in the translation choices here. Constantine's favorite word for oủoí $\alpha$ throughout the entire corpus of Orations is єстєство, and this makes him either limit the use of another word (сктьство) to only a few instances (altogether 6 of them in $C A I$ and $C A I I I$ ), or not use it at all (CAII and $C A I V$ ). Moreover, the consistency with which he applies єстєество primarily to God rather than man is another aspect that adds to the probability of a single translator of the Orations.

\section{2. Фúols}

Athanasius uses the word $\varphi \dot{\sigma} \sigma \varsigma$ (trans. as 'nature', 'substance', 'being') as a synonym of oủ $i^{\prime} \alpha$, and there are four ways in which Constantine renders it in Slavonic: сктьство, єстество, $\rho \mathcal{\prime} \mathbf{z} \mathbf{z}$, and твари. Of these four, the most frequent one is сктиство, while the other three (with the exception of $\rho \circ \mathbf{A} \mathbf{t}$ in

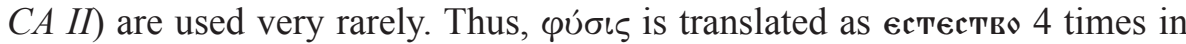
$C A I, 2$ times in $C A I I, 2$ times again in $C A I I I$, and never in $C A I V$. As $\rho \circ A^{\prime} \mathbf{z}$

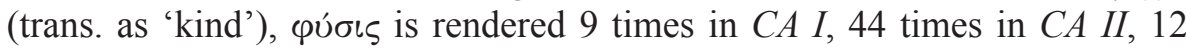
times in $C A I I I$, and only 1 time in $C A I V$. The word твaps (trans. as "created kind') for $\varphi v ́ \sigma \iota \varsigma$ occurs once in $C A I$ and nowhere else. In contrast, the word схтиство is used 46 times in CAI, 48 times in $C A I I, 73$ times in $C A I I I$, and 4 times in $C A I V$.

The translator uses all four words indiscriminately for depicting God and humanity/created state of things. Notably, there is a peculiar balance in the way єстество and сктиствв are used to describe God and humanity. Thus, the word єстєетво is applied 2 times to God and 2 times to humanity in $C A I, 1$ time to God and 1 time to humanity in $C A I I$, and again 1 time to God and 1 time to humanity in CA III. The word сктиствв is applied 20 times to God and 26 times to humanity/created state of things in CAI, 21 times to God and 27 times to man/created state of things in $C A I I, 41$ times to God and 32 times in CA III, 3 times to God and 1 time to humanity in $C A I V$.

Such a peculiar balance throughout the Orations, along with the consistent preference of сктиство over the other three words, suggest that there was a single translator of the entire Athanasian corpus. The main challenge here is to explain the striking increase in the number of times the word $\rho \circ A^{\mathbf{t}} \mathbf{b}$ is used in $C A I I$ : 44 instances over 9, 12, and 1 instances in $C A I$, III, and $I V$, respectively. If the increase is not the translator's own choice, there is a possibility that it was introduced by a later editorial redaction argued (on a different ground) 
by Penkova. ${ }^{12}$ She points out that $C A I I$ is the only Oration that does not demonstrate a consistent pattern in the way Constantine chooses to translate

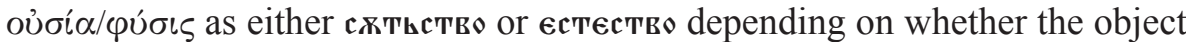
in question is God or humanity. Thus, in her selection of examples, she shows

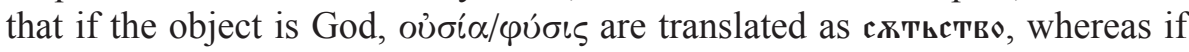
the object is humanity, they are translated as єстество. In Penkova's view, the fact that this pattern is observed in $C A I$ and $C A I I I$, but not in $C A I I$ is a witness to the later editorial redaction of this text.

In contrast to Penkova's observations, my own analysis ${ }^{13}$ has revealed that the complete textual data of the entire corpus of Orations does not support this pattern. In my conclusions, I contend that instead of distinguishing one word for God

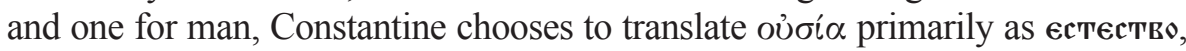

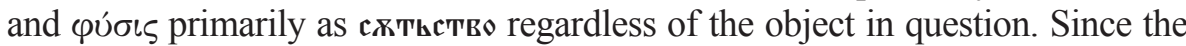
same translation strategy is consistently applied throughout the Orations, we can discern the work of a single translator here. Interestingly, Constantine's choice to

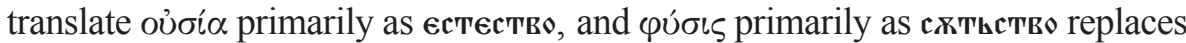
the opposite way of using these words by another representative of the Preslav Literary School - John the Exarch, Constantine's contemporary and colleague. In translating John of Damascus' Exposition of the Orthodox Faith (around the

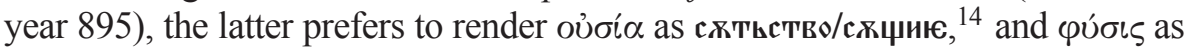
єстєство. In both cases, it is the consistency in the translation choices, pre-determined beforehand, that makes a significant textual factor.

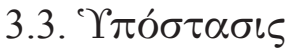

In most cases where Athanasius uses í $\pi$ ó $\tau \tau \alpha \sigma \iota$, he either borrows it from Hebrews 1.3, where Christ is described as the exact representation of the Fa-

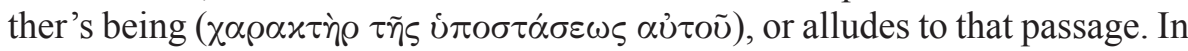
doing so, Athanasius argues that Christ's divine nature is equal with that of the Father (and the Holy Spirit). ${ }^{15}$ The term i $\pi$ ó $\sigma \alpha \sigma \iota \varsigma$ is used 16 times in the en-

\footnotetext{
${ }^{12}$ See the introduction where I briefly explain Penkova's point that of the four Orations, the second one underwent the subsequent redaction towards a strict verbatim translation. For more details, see PENKOVA 2016.a: 35-37.

${ }^{13}$ LYTVYNENKO (forthcoming).

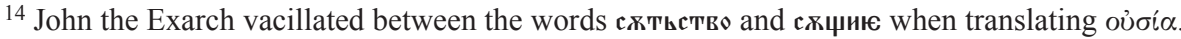
The later scribes replaced скцию by the then accepted term сктиство and used скцию to

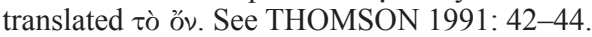

${ }^{15}$ The argument concerning the divine equality of the Holy Spirit with the Father and Son was articulated by Athanasius some 13 years after the Orations had been completed. Athanasius major work on the Holy Spirit is found in his three Epistles to Serapion on the Holy Spirit (CPG 2094), edited by WYRWA 2010.
} 
tire corpus of Orations, and Constantine chooses to render it in two ways: co-

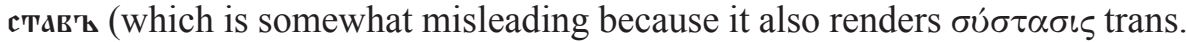
as 'constitution', 'disposition', 'setting together'), ${ }^{16}$ and ت̈nостась (a Slavonic loanword ${ }^{17}$ adopted from vं $\delta$ ó $\left.\tau \alpha \sigma \iota \varsigma\right)$. While we know that Constantine's contemporary, John the Exarch, drew a deliberate distinction ${ }^{18}$ between coctak' and ت̈nостась by using the former to describe the non-divine entities, and the latter to depict the persons of the Trinity, we cannot know whether Constantine preferred the same distinction. This is due to the fact that Athanasius uses i $\pi \delta \sigma \tau \alpha \sigma \iota \varsigma$ only in the trinitarian context and only to describe the Son. In the one exception where Athanasius applies i $\pi$ ó $\tau \alpha \sigma \iota \varsigma$ to the Father (CA III.66.7 [187a4]), Constantine translates it as ت̈nостась.

Constantine uses both words - состав's and ت̈nocracs - only in CA II and CA III: 1 occurrence of состав'ъ and 4 occurrences of ت̈nостась in the former, and 2 occurrences of составъ $\mathbf{s}$ and 4 occurrences of ت̈nостась in the latter. In $C A$ $I$, he uses only состав' (4 occurrences), and in $C A I V$, he uses only ت̈nоcтась (1 occurrence). Thus, if we discard $C A I V$ where $\dot{\pi}$ ó $\sigma \tau \alpha \sigma \iota \varsigma$ is used only once, we have two cases with состав' and ت̈nocracs in $C A I I$ and $C A$ III over one case with состав' the idea of several translators.

At the same time, it should be recognized that our manuscripts contain one clear instance of the scribal interaction with this terminology in CA II.32.18. More precisely, the misspelled word стьставна for состав' that says кто съдыєеть ГАаголати, тоуждєГо сжшта начрттаниа стыставна

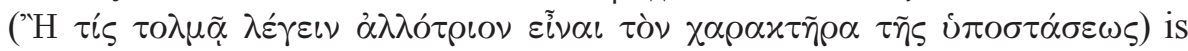
corrected in the margins by the word ипостаси (the genitive of $\dot{\eta} \dot{\delta} \pi \delta \sigma \tau \alpha \sigma \iota \varsigma$ ) in three of the four manuscripts that were copied directly from the lost Old Bulgarian protograph. ${ }^{19}$ This situation should alert us to the possibility that

${ }^{16}$ The same situation is observed in John the Exarch's translation of John of Damascus' Exposition of the Orthodox Faith, see PODSKALSKY 1970: 154-158, esp. 157. For a discussion of the Slavonic rendering of $\dot{\pi} \pi$ ó $\tau \alpha \sigma \iota \varsigma$ in various texts, including those of the Preslav School, see HRISTOVA-SHOMOVA 2016: 108-126.

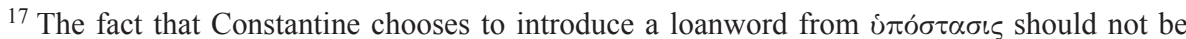
understood as a lack of Greek proficiency on the part of the translator. Rather, it shows that for him no Slavonic word could do adequate justice to the meaning of this Greek term. See WEIHER 1972: 146.

${ }^{18}$ On this, see THOMSON 1991: 43-44.

${ }^{19}$ The three manuscripts in question are: St. Petersburg, RNB, Sobranie Pogodina 968; Moscow, RGB, Sobranie Ovčinnikova F.209, 791; Moscow, RGB, Sobranie Volokolamskogo monastyrja F.113, 437. The same correction is reproduced in five other manuscripts that were copied from the Russian copies of the Old Bulgarian protograph. For the details concerning 
during the manuscript transmission of the Orations (between 908 and 1489), ${ }^{20}$ coctak's could become ت̈noctrack, and vice versa. Therefore, it is important to stress that any observations about the original status of these two words should be provisory rather than conclusive.

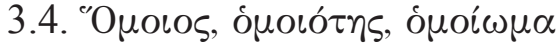

In the trinitarian context, Athanasius uses this group of words (trans. as 'like', 'likeness' 'similar', 'similarity') to describe the ontological equality between Christ and the Father. At the time of the composition of the first three Orations in 339-345, Athanasius was reluctant to employ a more precise term

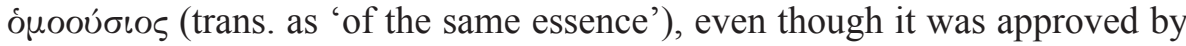
the Council of Nicaea in 325 and used in the Creed. Apparently, the reason for that reluctance had to do with the misunderstanding caused by the word

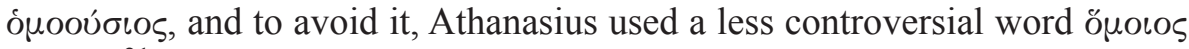

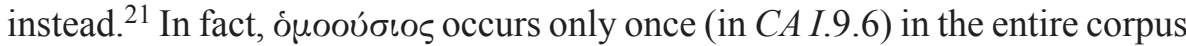
of the Orations, and it is not until after the mid-350s that Athanasius began

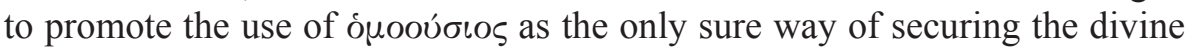
equality between the persons of the Trinity. During this time, the trinitarian controversy became considerably more complicated with the appearance of four different parties: the homoousians (led by Athanasius), the homoiousians, the homoians, and the anomoians, each arguing respectively, that Christ is either 'of the same being' as the Father, or 'like him in his being', or simply 'like' the Father, or entirely 'unlike' him. ${ }^{22}$

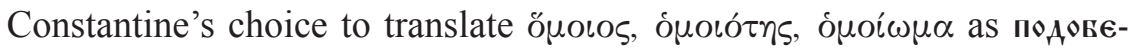
нт//подовие and точент/точеньство makes an important case of reception. In tune with the Preslav principles of translating one Greek word with several

the relationship between the manuscripts, as well as for the textual situation in CA II.32.18, see LYTVYNENKO (forthcoming).

${ }^{20}$ The transmission period of Orations begins in 908 when they were copied for the first time in Bulgaria, while the year 1489 marks the time when the lost Old Bulgarian protograph was copied by the scribes of the manuscripts: St. Petersburg, RNB, Sobranie Pogodina 968 and Moscow, RGB, Sobranie Volokolamskogo monastyrja F.113, 437. The date of copying of the third manuscript can only be determined approximately as the end of the $15^{\text {th }}$ century. The rest of 7 manuscripts are dated by the $16^{\text {th }}$ century, with the exception of one that is dated by the $17^{\text {th }}$ century. For the details on the manuscript tradition, see LYTVYNENKO (forthcoming).

${ }^{21}$ For the theological background concerning ónoov́oı BEHR 2004: 136-139, 157-158.

${ }^{22}$ On this see ANATOLIOS 2004: 22-25. 
Slavonic equivalents, ${ }^{23}$ Constantine is linguistically most close to Athanasius'

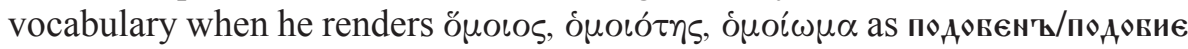
(trans. as 'like'/'likeness'). At the same time, the translator's choice to render these Greek words as точен'ъ/точеньство (trans. as 'exact'/“exactness') captures the central point of the Orations - that Christ's divine nature is identical with that of the Father - even more precisely.

It should be stressed, though, that Constantine's preferred option throughout

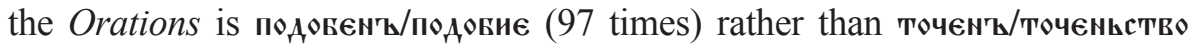
(15 times). The former is used 26 times in CA I, 27 times in CA II, 40 times in $C A I I I$, and 4 times in $C A I V$. In contrast, the latter is used 7 times in $C A$ $I, 6$ times in $C A I I, 2$ times in $C A I I I$, and never in $C A I V$. For our purposes, however, it is important to register a consistent pattern here. It is marked by the preference of one term over the other in all four Orations, as well as by the presence of both terms in the first three Orations. This again can be indicative of a single translator.

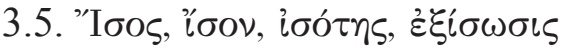

These words are part of Athanasius' vocabulary in the first three Orations but not in the fourth one. Just as with the previous terminology, Athanasius'

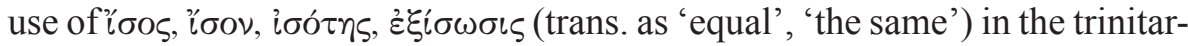
ian context has the aim of articulating the equal status of Christ and the Father in the one Godhead. Constantine translates these words in three ways: точен's

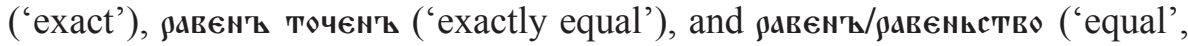

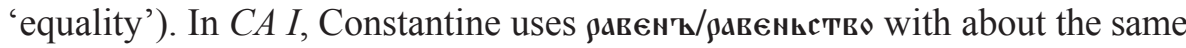
frequency as точенъ (6 times over 7), and he employs равєн' точен'ъ only

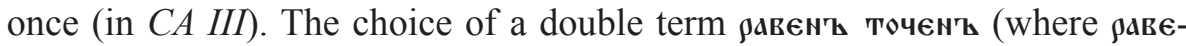
нъ and точенъ have a similar meaning) for one single Greek word is quite unusual. It may indicate the translator's desire to intensify the idea of identity between Christ and humans in the particular context where it is used (see $C A$ III.17.22). ${ }^{24}$

The most obvious consistency with regard to these terms is observed in

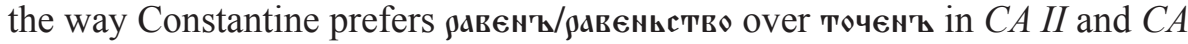
III. The word точєе ' is used only 1 time in $C A I I$, and once again in $C A I I I$,

\footnotetext{
${ }^{23}$ See the introduction.

${ }^{24}$ CA III.17.21-23 (METZLER; SAVVIDIS 2000: 327; PENKOVA 2016.a: 148b14-16). The

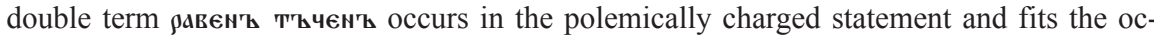

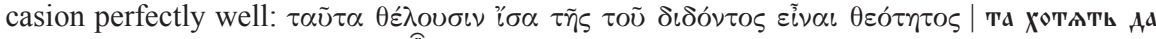

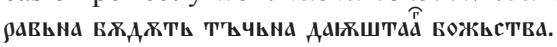


whereas The reason for such preference may have to do with the fact that точе $\mathrm{N}$ '

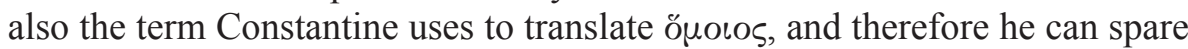
its use in relation to " 6 бо indeed the case, it can suggest a single translator of the Orations.

\subsection{Móvos}

In the trinitarian context, Athanasius uses the word $\mu$ óvos (trans. as 'one', 'single') both to emphasize the uniqueness of God as Trinity (or Father as the only fountain of divinity), and to draw a contrast between Christ on the one hand, and creatures on the other. Constantine chooses to translate this word with two different Slavonic equivalents: єдин'ъ (trans. as 'one') and сц'Тгл'ъ/ ц'E' $\mathbf{A}^{\prime} \mathbf{\mathbf { b }}$ (trans. as 'sole', 'private'). The second of these two is recognized as a very rare term, and there are only a few other Slavonic sources where it occurs outside of the Orations. ${ }^{25}$ One of these sources is believed to be another translation completed by Constantine of Preslav. This work, known as the Didactic Gospel, contains a collection of fifty-one homilies from John Chrysostom and Cyril of Alexandria and was translated from the popular Byzantine catenae (or

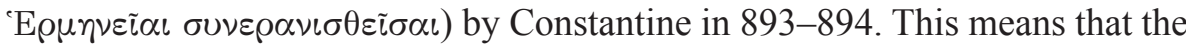
Didactic Gospel was completed some 13 years before Constantine finished translating the Orations in $907 .{ }^{26}$ In the Didactic Gospel, the word сц'Кг's is used only once, and Constantine employs it to translate the Greek phrase $x \alpha \tau$ ' $i \delta i \alpha \nu$ that describes one's healing made in private. ${ }^{27}$

In translating the Orations, Constantine continues to use сц'вгл' $\mathbf{z}$ in the mundane sense in relation to humans and created objects, but he also converts it into a theological term to depict Christ's uniqueness. In $C A$ II and CA III, сц'КГл' is used 8 times with regard to God/divinity, 7 times with regard to Christ, and 2 times with regard to humans/created objects. By far, Constan-

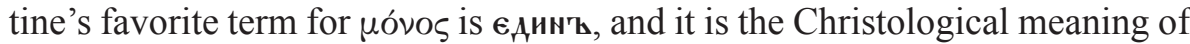
this word that outnumbers all other senses. Thus in $C A I$, it is used 10 times to Christ, 6 times to God/divinity, and 2 times to non-divine things; in $C A I I$, it

\footnotetext{
${ }^{25}$ These sources are indicated in MIRČEVA (forthcoming) and discussed in PIRINKA 2016.b. For the etymological analysis of this word, see FASMER 1971: 323.

${ }^{26}$ Each homily in the Didactic Gospel is prefaced by Constantine's own introductions and ends with his brief concluding remarks. The best manuscript that preserves the Didactic Gospel is Moscow, GIM Sin. 262 (late $11^{\text {th }}-$ early $12^{\text {th }} \mathrm{c}$.), published (along with the corresponding Greek text from the edition of J. A. Cramer) by TICHOVA 2012.

27 TICHOVA 2012: 74b15.
} 
is used 20 times to Christ, 15 times to God/divinity, and never to other things; in $C A I I I$, it is used 14 times to Christ, 13 times to God/divinity, and 8 times to non-divine things; and finally in $C A I V$, it is used 3 times to Christ, 1 time to God/divinity, and 1 time to non-divine things.

Here what might point to a single translator is the consistency with which $\varepsilon_{\text {дин' }}$ is chosen to enjoy the dominant position over сц'тгл' throughout the Orations, along with the fact that such a rare term as сц'Кг $\mathbf{s} \mathbf{k}$ is used in both works that Constantine translated into Old Slavonic - the Orations and the Didactic Gospel.

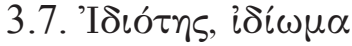

Athanasius uses these words primarily to define Christ's relation to the Father (17 times in the Orations), although they also appear once in the context of his discussion of Christ's assumed body, and once when he argues for a special sense of particular words in Scripture. Both of these words stem from a much more frequent term ' $\delta\llcorner\circ \varsigma$, and it has long been established that this adjective functions as a technical term in Athanasius' writings. It occurs 682 times in the form of ' $\delta$ เ

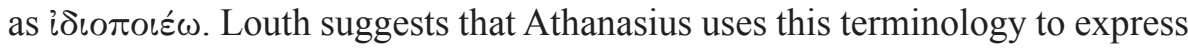
the idea of substantial inseparability in two types of relations: between the Father and Son, and between Christ and his body. ${ }^{28}$

After being translated by Constantine, the technical term i $\delta$ เos received two different expressions in the Old Slavonic: свои єго/своє ємоү ${ }^{29}$ translated

${ }^{28}$ LOUTH 1989: 198-200. See also FAIRBAIRN 2002: 85-90. One could add that Athanasius applies the same terminology for the description of the relation between the subject and qualities. The divine qualities do not exist by themselves; they belong to the Father in whom they are properly indwelled. And since the Son is the Father's natural offspring, the same qualities are proper to him as well (LYTVYNENKO 2014: 228-230).

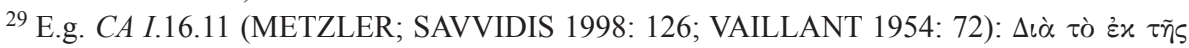

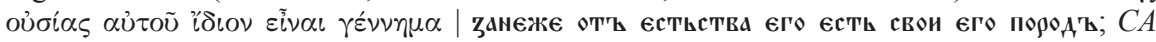
III.32.12-18 (METZLER; SAVVIDIS 2000: 343; PENKOVA 2016.a: 160б.15-20): हैं

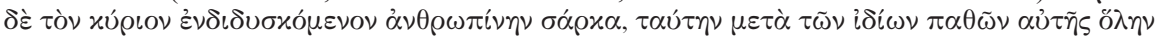

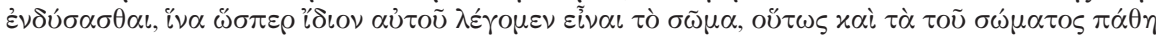

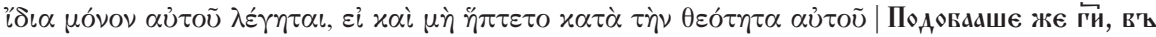

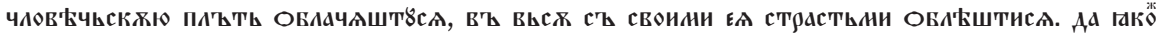

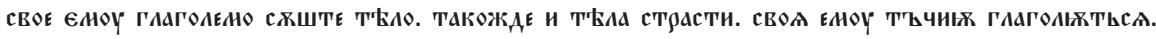

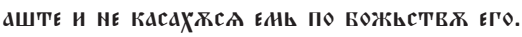


as 'his own', and приснєн'ъ ${ }^{30}$ translated as either 'eternal', or 'genuine', or 'one's own' and 'proper to'. These words brought additional semantic variety into the text of the Orations, and they represent a beautiful example of the reception of Athanasius' thought in the Slavonic tradition. Even more variety

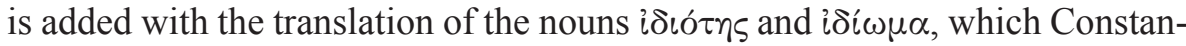
tine renders in three ways: присносжштиство (trans. as 'eternality'), своиство (trans. as 'property'), and овычаи (trans. roughly as 'custom', 'usage', 'something to which customary things are proper'). Of these three, свонство is the most frequently used: it occurs 14 times ( 3 in $C A I$, again 3 in $C A I I$, and 8 in $C A I I I)$ as opposed to 3 occurrences for other terms (присносжштыство is used once in $C A I$ and once in CA II, and овычли is used once in CA III).

Here, the most attractive aspect for the case of a single translator is the fact that the Slavonic variety of the ' $\delta$ ios word-group is evidently preserved in the form of свои его/свое еноу, присненты, and своиство throughout the Orations.

\subsection{Eĩ $\alpha \iota$}

One other notable case that can be indicative of a single translator of the

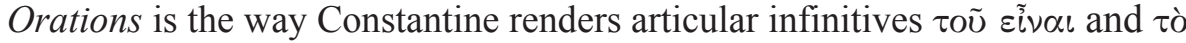

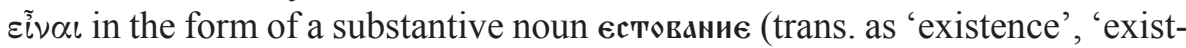
ing'). Being a distinctly Constantinian word, it derives from the verb єсть ('to be') and is semantically related to the word єстество ('substance' or 'being'), which is Constantine's favorite word for translating oủ $\sigma i \alpha$.

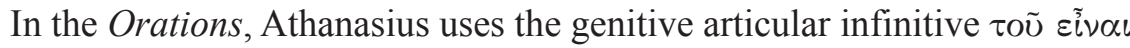

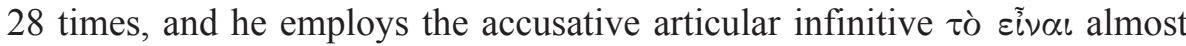
twice as often -48 times. Of these 76 cases, Constantine chooses only 15 to translate as eстованиe. He does so 1 time in $C A I, 10$ times in $C A I I, 1$ time in $C A I I I$, and 3 times in $C A I V$. In 13 of these instances, Constantine applies

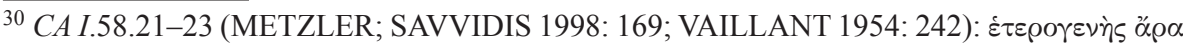

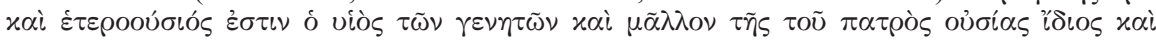

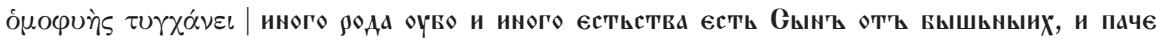
Присньн'ъ ОтчА єстьсттва и тождєс४штен'ъ єстт; СА III.33.19-22 (METZLER; SAVVIDIS

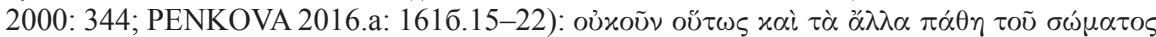

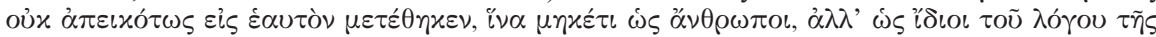

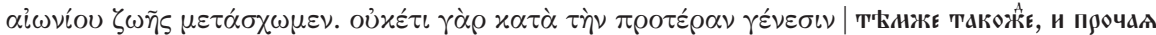

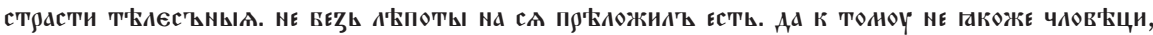

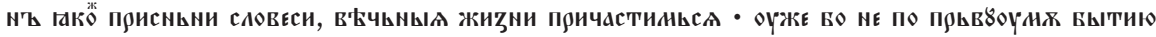

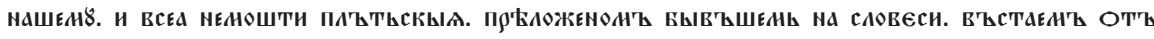
z૯HAN. 
єстованиє to Christ, and in 2 instances (both in $C A I I$ ), he uses this word in relation to humanity/creation. Thus, it is the Christological sense of eстование that Constantine prefers (often with the purpose of underscoring the fact that Christ has no beginning of existence when compared to creatures that began to exist), and we have at least one occurrence of this word in each of the four Orations. This being the case, єстование provides another textual example that can lend support for a single translator of the Orations.

\section{CONCLUSION}

If the plausibility of a single translator is more likely than not, then two points are worth making in conclusion. First, once we know that the entire corpus of Slavonic Orations is the work of the Preslav translator, we may have more confidence in using the Orations for reconstructing the translation principles of the first literary school in the medieval Bulgarian Empire, the so-called Preslav Literary School (active from 885 to 972). ${ }^{31}$ As we know, the School was the most important literary and cultural center of all Slavs, and its representatives, such as Constantine himself, were responsible for the pioneering work of translating numerous patristic texts into Slavonic. Constantine's translation of the Orations in 907 was very likely to impact some of these projects on the most fundamental level.

Second, given the consistency with which one single Greek word is translated with two or more Slavonic equivalents, and the pattern in which they are used throughout the Orations, it is reasonable to suggest that our selected terms were either not affected by a later editorial work, or the editor was responsible for the kind of consistency that is observed with regard to their usage. ${ }^{32}$ Here the question worth exploring further is to what extent does $C A$ II demonstrate particular linguistic differences when compared with the other Orations? To establish this, it would be helpful if more work, similar to this one, would be done in the future.

\footnotetext{
${ }^{31}$ See e.g. THOMSON 1991: 35-58; HANSACK 1981: 15-36.

${ }^{32} \mathrm{~A}$ reasonable question to ask here is whether the differences in the manuscript tradition between $C A I I$ and $C A I I I$ have to do with the likelihood of editorial interference, or with the possibility that the Greek manuscripts available to Constantine already belonged to divergent textual traditions? Hopefully, further research will help to bring more clarity on this issue.
} 


\section{SOURCES}

CA I = Oratio I contra Arianos. Slavonic edition: VAILLANT, A. (éd.). 1954. Discours contre les Ariens de Saint Athanase. Version slave et traduction en français. Sofia: Académie des sciences de Bulgarie.

Greek edition: METZLER, K.; K. SAVVIDIS (hrsg.). 1998. Orationes I et II contra Arianos, Athanasius Werke, Die dogmatischen schriften. Band II. Teil 1. Lieferung 2. Berlin-New York: Walter de Gruyter.

CA II = Oratio II contra Arianos. Slavonic editions: PENKOVA, P. 2015 (red.). Vtoro Slovo protiv arianite v starobŭlgarski prevod. Tom 1. Sofia: Zapad-Iztok; LYTVYNENKO, V. (ed.). (forthcoming). Oratio II Contra Arianos: Old Slavonic Text and English Translation. Turnhout, Belgique: Brepols (=Patrologia Orientalis).

Greek edition: METZLER, K.; K. SAVVIDIS (hrsg.). 1998. Orationes I et II contra Arianos, Athanasius Werke, Die dogmatischen schriften. Band II. Teil 1. Lieferung 2. Berlin-New York: Walter de Gruyter.

CA III = Oratio III contra Arianos. Slavonic edition: PENKOVA, P. 2016.a (red.). Sv. Atanasij Aleksandrijskij, Treto Slovo protiv arianite. Izsledvane i izdanie na teksta. Tom 2. Sofia: Izdanie Valentina Trajanova.

Greek edition: METZLER, K.; K. SAVVIDIS (hrsg.). 2000. Orationes III contra Arianos. Athanasius Werke. Die dogmatischen schriften. Band I. Teil 3. Berlin-New York: Walter de Gruyter.

CA IV = Oratio IV contra Arianos = Epistula ad episcopos Aegypti et Libyae. Slavonic version: Sobranie Pogodina 968, 1489, St. Petersburg, National library of Russia.

Greek edition: METZLER, K.; K. SAVVIDIS (hrsg.). 1996. Epistula ad episcopos Aegypti et Libyae, Athanasius Werke, Die dogmatischen schriften. Band I. Fascicle 1. Berlin-New York: Walter de Gruyter.

CPG = Clavis Patrum Graecorum. 1974-2003. Turnhout: Brepols Publishers.

\section{BIBLIOGRAPHY}

ANATOLIOS, K. 2004. Athanasius. London: Routledge.

ANGELOV, B. 1987. Ioann Ekzarch o trude perevodčika. L. A. Dmitriev (Hg.) Issledovanija po drevnej i novoj literature. Leningrad: Nauka, 22-25.

BEHR, J. 2004. The Formation of Christian Theology: The Nicene Faith. Part One: True God of True God. Vol. 2. New York: St. Vladimir's Seminary Press.

ČERNYŠEVA, M. I. 1994. Nekotoryje soobraženija po povodu gruppirovki ranneslavjanskich perevodov s grečeskogo jazyka po perevodčeskim prijomam. Vizantinorussica 1: $62-75$.

FASMER, M. 1971. Etimologičeskij slovar'russkogo jazyka. Moskva: Progress. 
FAIRBAIRN, D. 2002. Grace and Christology in the Early Church. Oxford: Oxford University Press.

FLOËRI, F.; P. NAUTIN (éd.). 1957. Homélies pascales III. Une homélie anatolienne sur la date de Pâques en l'an 387. Paris: Le Cerf (=Sources chrétiennes 48).

GITTON, M. 2006. La théologie trinitaire d'Athanase d'Alexandrie. Paris: Institut des Études Augustiniennes.

GORSKIJ, A.; K. NOVOSTRUEV. 1859. Opisanie slavjanskich rukopisej Moskovskoj sinodalnoj biblioteki. Otdel 2. Čast 2. Moskva: Sinodalnaja tipografia.

HANSACK, E. 1981. Die theoretische Grundlagen des Übersetzungsstils des Exarchen Johannes. Die Welt der Slaven XXVI: 15-36.

HRISTOVA-SHOMOVA, I. 2016. Bog be slovo. Sofia: Universitetsko izdatelstvo Sv. Kliment Ochridski.

KALAJDOVIČ, K. 1824. Ioann Ekzarch Bolgarskij: Issledovanie, objasnjajušeje istoriju slovenskogo jazyka i literatury IX i XI stoletij. Moskva: Tipografia Selivanovskogo.

LOUTH, A. 1989. The Use of the Term $\delta \iota \varsigma_{\text {in }}$ Alexandrian Theology from Alexander to Cyril. Studia Patristica 19: 198-200.

LYTVYNENKO, V.; I. GRITSEVSKAYA. 2017. Sočinenia Afanasia Aleksandrijskogo v slavjanskoj tradicii. Čast I: Podlinnye sočinenia. Byzantinoslavica 75: 5-29.

LYTVYNENKO, V. 2014. The Doctrine of God and Deification in Athanasius of Alexandria: Relations and Qualities. Prague: Charles University. Diss. URL=https://is.cuni. cz/webapps/zzp/detail/91319/?lang=en (October 13, 2018).

LYTVYNENKO, V. (ed.). (forthcoming). Oratio II Contra Arianos: Old Slavonic Text and English Translation. Turnhout, Belgique: Brepols (=Patrologia Orientalis).

METZLER, K.; K. SAVVIDIS (hrsg.). 2000. Orationes III contra Arianos. Athanasius Werke. Die dogmatischen Schriften. Band I. Teil 3. Berlin-New York: Walter de Gruyter.

METZLER, K.; K. SAVVIDIS (hrsg.). 1998. Orationes I et II contra Arianos, Athanasius Werke, Die dogmatischen Schriften. Band II. Teil 1. Lieferung 2. Berlin-New York: Walter de Gruyter.

METZLER, K.; K. SAVVIDIS (hrsg.). 1996. Epistula ad episcopos Aegypti et Libyae, Athanasius Werke, Die dogmatischen Schriften. Band I. Fascicle 1. Berlin-New York: Walter de Gruyter.

MILTENOV, Ja. 2008. Leksičeskij kriterij kak sposob atribucii preslavskich tekstov. Slavjanovedenie 5: 41-49.

MIRČEVA, E. (forthcoming). Redki leksemi v starobŭlgarskija knižoven jayik. Preslavska knižovna škola 17.

PENKOVA, P. 2016.a (red.). Sv. Atanasij Aleksandrijskij, Treto Slovo protiv arianite. Izsledvane i izdanie na teksta. Tom 2. Sofia: Izdanie Valentina Trajanova.

PENKOVA, P. 2016.b. Vŭzpriemaneto na Atanasij Aleksandrijski v zapadnata tradicia i vlianieto i vŭrchu Konstantin Preslavski v prevoda na Slovata protiv Arianite. $\boldsymbol{S}$ taw $X-X X I, \quad I V / 8 . \quad$ URL $=$ http://www.abcdar.com/magazine/VIII/Penkova_1314-9067_ VIII.pdf (October 13, 2018). 
PENKOVA, P. 2015 (red.). Vtoro Slovo protiv arianite v starobŭlgarski prevod. Tom 1. Sofia: Zapad-Iztok.

PENKOVA, P. (ed.). 2008. On the Authorship of съданїє • праздницт пасхы Attributed to Athanasius of Alexandria. Scripta \& e-Scripta 6: 279-303.

PODSKALSKY, G. 1970. Untersuchungen zu einigen Zentralbegriffen der patristischen Personspekulation in der vom Exarchen Johannes geschaffenen slavischen Uberset-

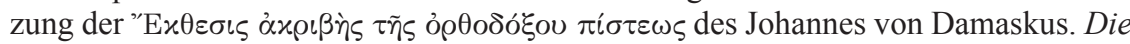
Welt der Slaven 15: 147-167.

POPKONSTANTINOV, K.; V. KONSTANTINOVA. 1984. Kŭm vŭprosa za černorizec Tudor i negovata pripiska. Starobŭlgarska literatura 15: 106-118.

POPOVA, T. 2010. K Voprosu ob avtorstve preslavskogo perevoda lestvicy Ioanna Sinajskogo. Russkaja filologija 4: 44-47.

STEAD, C. 1977. Divine Substance. Oxford: Clarendon Press.

STEGMANN, A. 1917. Die pseudoathanasianische 'IVte Rede gegen die Arianer' als

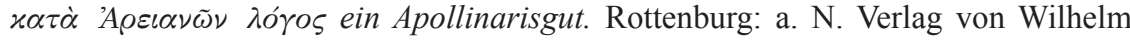
Bader.

TACHIAOS, A. 2001. Cyril and Methodius of Thessalonica: The Acculturation of the Slavs. New York: St. Vladimir's Seminary Press.

THOMSON, F. 1991. John the Exarch's Theological Education and Proficiency in Greek as Revealed by his Abridged Translation of John of Damascus' De fide Orthodoxa. Palaeobulgarica 1: 35-58.

TICHOVA, M. 2012. Starobolgarskoto Učitelno Evangelie na Konstantin Preslavski. Tom LVIII. Freiburg I. Br.: Weiher.

VAILlANT, A. (éd.). 1954. Discours contre les Ariens de Saint Athanase. Version slave et traduction en français. Sofia: Académie des sciences de Bulgarie.

VINZENT, M. 1996. Pseudo-Athanasius. Contra Arianos IV. Eine Schrift gegen Asterius von Kappadokien. Band XXXVI. Leiden-New York: E. J. Brill.

WEIHER, E. 1972. Zur sprachlichen Rezeption der griechischen philosophischen Terminologie im Kirchenslavischen. Anzeiger für slavische Philologie 6: 138-159.

WYRWA, D. (hrsg.). 2010. Epistula I-IV ad Serapionem, Athanasius Werke, Die dogmatischen Schriften. Band I. Teil 1. Lieferung 4. New York-Berlin: Walter De Gruyter.

ZIZIOULAS, J. 1997. Being as Communion. Studies in Personhood and the Church. New York: St. Vladimir's Seminary Press.

ZYKOV, E. 1978. O literaturnom nasledii Konstantina Preslavskogo. Starobŭlgarska literatura 3: 34-47. 
Sažetak

Viacheslav V. Lytvynenko

\section{ODABRANI TEKSTNI DOKAZI KAO ARGUMENT ZA JEDINSTVENOGA PREVODITELJA ATANAZIJEVIH GOVORA PROTIV ARIJEVACA NA STAROSLAVENSKI}

Cilj je članka argumentirati pretpostavku o jednom prevoditelju Atanazijevih (triju) Govora protiv Arijevaca i Pisma biskupima Egipta i Libije (poimana kao četvrti govor u staroslavenskom korpusu) na staroslavenski jezik. U tu svrhu istražuje se osam grčkih termina, koji predstavljaju temeljni vokabular u raspravama o trojstvenosti u 4. stoljeću i u samim Atanazijevim Govorima, i njihovi slavenski ekvivalenti. Prvi dio rada donosi iscrpnu terminološku tablicu koja sadrži spomenutih osam grčkih termina i njihove slavenske ekvivalente u svim četirima pismima. Na temelju terminološke tablice u drugom se dijelu rada raščlanjuju odabrani termini. Istražuje se dosljednost njihove uporabe u Atanazijevim govorima kao argument da se staroslavenski prijevod Govora protiv Arijevaca može smatrati radom jednoga prevoditelja.

Ključne riječi: Atanazije Aleksandrijski, Govori protiv Arijevaca, staroslavenski prijevod, Konstantin Preslavski, preslavska književna škola 